\title{
General Agreement on Trade in Services and Higher Education in China
}

\author{
Xiaobin Li (Brock University) \\ Linbin Zhao (Minjiang University, Fuzhou, Fujian, PRC)
}

\begin{abstract}
The Chinese higher education system is the largest in the world. Having an understanding of the Chinese system helps to provide a better understanding of international education. This article discusses the commitments China has made under the General Agreement on Trade in Services (GATS), these commitments' implications for Chinese higher education, and Chinese attitudes towards foreign education. It also discusses the recent development of international cooperation in Chinese higher education. Chinese are interested in learning from developed countries, the demand for higher education continues to grow in China, and most Chinese scholars believe internationalization is beneficial. Indications are Chinese higher educators will expand their cooperation with international colleagues to meet changing social needs. In internationalizing Chinese higher education, GATS may play a facilitating role.
\end{abstract}

\begin{abstract}
Résumé
L'éducation supérieure chinoise est la plus grande du monde. Comprendre le système chinois aide à comprendre le système international. Cet article discute les accords que la Chine a pris en signant l'Accord Général sur le Commerce des Services (AGCS), les implications pour l'éducation supérieure chinoise et les attitudes chinoises envers l'éducation étrangère. Il expose également les derniers développements de coopération internationale dans l'éducation supérieure chinoise. Les chinois sont intéressés à apprendre des pays développés. La demande d'éducation supérieure continue à croître en Chine et la plupart des intellectuels chinois pensent que l'internationalisation est positive. Les professeurs d'éducation supérieure chinoise vont donc chercher à accroître la coopération avec leurs collègues internationaux afin de répondre aux besoins sociaux actuels. L'AGCS jouera certainement un rôle majeur dans l'internationalisation de l'éducation supérieure de ce pays.
\end{abstract}

\section{INTRODUCTION}

On December 11, 2001, China joined the World Trade Organization (WTO). That was a significant development for the Chinese economy, as well its higher education, because it marked the establishment of formal trade links between China and the rest of the world. One consequence is the increased awareness of internationalization among Chinese higher educators. This article discusses the commitments China has made under the General Agreement on Trade in Services (GATS) and their implications for Chinese higher education. The article also describes Chinese attitudes toward foreign education. It discusses the recent development of Chinese higher education in international cooperation. It concludes with a discussion of the role GATS may play and the potential impact the internationalization of Chinese higher education may have.

By joining the WTO, China demonstrated its increasing participation in 
the world economy and its willingness to follow the relevant rules. China has become more involved in an opening yet still regulated international market. In order for China to take its place in the world economy, Chinese entrepreneurs and workers have to compete with international colleagues under the principle of nondiscrimination with regard to domestic and foreign goods and services.

For many decades international trade mainly involved goods; trade in services was secondary. Over the past thirty years, however, trade in services has grown faster than trade in goods. To promote the former, 149 countries negotiated and signed the General Agreement on Trade in Services (GATS). It came into force in January 1995 and has since become an important WTO agreement (WTO, 2006).

According to the Manual on Statistics of International Trade in Services, there are 12 major service sectors: business, communications, construction and engineering, distribution, education, environmental services, financial services, health and social services, tourism and travel, recreational, cultural, and sporting services, transportation, and other services not included elsewhere (WTO, 2002). In this classification scheme, educational services are further divided into five subsectors: primary, secondary, higher, adult and other education (WTO, 1991).

Article II of GATS promotes most-favoured-nation treatment; Article XVI urges the opening up of markets; Article XVII requires members to extend national treatment to service suppliers of all other members (WTO, 1994). However, Clause 1 of Article XIII stipulates that Articles II, XVI, and XVII shall not apply to laws and regulations governing the procurement by governmental agencies of services purchased for governmental purposes, i.e. services not intended for commercial resale (Varoglu, 2002).

In many countries primary and secondary education is mainly services purchased for governmental purposes without the intention of commercial resale. By contrast, higher education and adult education tend to rely more on private sources of financing and are more likely to be engaged in commercial activities. It follows that higher and adult education systems are more likely to be considered services with a view to commercial resale. Thus, it is mainly in higher and adult education that governments must decide whether to open their market and to what extent.

Under GATS, education is being liberalized and transformed into a multi-billion dollar industry, powered by market-liberalization proponents in the developed economies, in particular the US, the EU, Japan, New Zealand and Australia (Robertson, 2003). At the WTO talks held in Hong Kong in December 2005, the United States identified the liberalization of higher and adult education services as one of its top four priorities (Czernis, 2005). The United States 
wanted China to remove the restriction on foreign education services provided through satellites and the requirement that foreign education providers must cooperate with Chinese (Lu \& Zha, 2004). A new multilateral group, Friends of Private Education Exports, has formed in New Zealand; its goal is to gain more commitments from more countries regarding education services (Canadian Association of University Teachers, 2006). In the last round of WTO negotiations in Geneva in July 2008, Australia and New Zealand pushed other members to open up their education sector to private offshore competition (Education International, 2008). "It appears that almost all elements of higher education systems are potentially impacted by GATS" (Vlk, 2006, p. 108).

There are four possible modes for providing education services (WTO, 2002). With mode one, cross-border services, the consumers of education services remain in their own country with the suppliers located in another country. Network education and correspondence education are examples of crossborder services. Currently, some Chinese students are receiving education provided by foreign institutions through the Internet.

With mode two, consumption abroad, students leave their home country to be educated in another country. Between 1978 and 2008 about 1.4 million Chinese went abroad to receive further education. In 2008 alone approximately 179,800 Chinese went overseas for education (Ministry of Education, March 25, 2009).

With mode three, commercial presence, institutions establish a commercial presence abroad to provide services to consumers in their home country. Foreign-owned and cooperative schools are examples of this mode. There are cooperative universities designed and operated jointly by a hosting Chinese institute and a foreign institute.

With mode four, presence of natural persons, individual service providers move to the consumers' country (WTO, 2002). Today, more foreign scholars are teaching in China, and an increasing number of Chinese scholars are teaching in other countries.

\section{IMPLICATIONS OF THE GENERAL AGREEMENT ON TRADE IN SERVICES}

When the Chinese government signed the GATS, it stated its position regarding education services: (1) China would not open its market in primary and junior secondary education, in military and police training, and in political education. (2) Restrictions would not be placed on Chinese traveling overseas for education or on foreign nationals entering China for education. (3) With certain conditions, China would gradually open its higher education, adult education, and other education. 
Foreign educational institutions would be allowed to cooperate with Chinese institutions. These foreign institutions would be expected to abide by the Regulation on Sino-Foreign Collaborative Education of the People's Republic of China. (4) When employed or invited by Chinese institutions, foreign educators would be permitted to work in China (WTO, February 14, 2002). Actually, China is the only country among Economic and Social Commission of Asia and Pacific members that has extended its commitments to liberalize access in all five subsectors of education services (Raychaudhuri \& De, 2007).

GATS is part of the WTO, which means its regulations are binding on national governments. The general aim of GATS is to expand international trade in services in ways that promote economic growth for all member states, including developing countries (WTO, 1994). To expand trade in services under conditions of progressive liberalization, Articles II, XVI and XVII promote mostfavoured-nation treatment, an open market, and national treatment. This means member governments are expected to loosen their control over education and to reduce and even eliminate restrictive education acts and regulations. Under GATS, any educational activities that charge tuition can be considered trade in services. The goal is for these services to be opened gradually to service providers from other member countries.

GATS signatories are encouraged to help their education institutions become more international. This includes allowing international institutions to provide degree and certificate programs in signatory countries. Signatories are also encouraged to acknowledge one another's degrees and certificates, to reduce immigration restrictions to increase the international mobility of educated people, to eliminate monopolies over education, and to reduce subsidies to domestic institutions.

These common rules represent a serious challenge to the Chinese higher education system, which has been under almost complete government control since 1949, when the Communists came to power after winning a four-year civil war. But these same rules can also be viewed as an opportunity that, if recognized and seized, will facilitate the transformation of the Chinese higher education system and help to establish an environment in which the system can develop in ways that better address social needs.

The WTO is an international body that coordinates economic relationships, promotes international exchanges of personnel, and encourages cooperation among members. Most WTO members signed GATS in order to promote international trade in services.

Education systems are complex by nature, and GATS recognizes that developing countries need to be able to regulate their own systems in order to 
meet national policy objectives (WTO, 1994). Furthermore, many WTO members have not specifically committed themselves to opening their education services. After health, educational services are the sector in which the members have established the fewest commitments on liberalization (Verger, 2008). As of August 2006, only 39 WTO members made a commitment to liberalize access to their higher education services (Raychaudhuri \& De, 2007). Those that have done so have attached various conditions to their commitments.

Since China made specific commitments to open its education services under GATS (WTO, February 14, 2002), more foreign instructors are working in Chinese higher education. Naikai University in Tianjin started recruiting chair professors globally in 2004 and deans of colleges in 2006 (Guan, 2006). On May 10, 2007, Austrian physicist Romano A. Rupp was appointed the Dean of the Taida Institute of Applied Physics of Nankai University. Dr. Rupp was a professor at the University of Vienna before accepting the appointment at Nankai (Nankai University, 2007). As the number of international scholars working in Chinese institutions increases, more international students are attending Chinese universities. According to the Ministry of Education (December 4, 2009), almost 230,000 international students studied in Chinese universities in 2009. The three main sources of international students were South Korea, the United States and Japan (Ministry of Education, March 25, 2009). In recent years, the increase of international students going to China surpassed the increase of Chinese students going overseas (Zhang, 2008). Most international students are self-financed, with about six percent of them on Chinese government scholarships (Ministry of Education, March 25, 2009).

Improvement of the Chinese higher education structure should be considered not only from the perspective of domestic modernization but also from the perspective of international competition. International competition will certainly increase the demand for educated people. China needs well-educated citizens, who will contribute to society and can compete with international colleagues.

By signing GATS, China put itself on course to narrow the gap between its higher education system and those of developed countries. To Chinese educators, the benefits of signing GATS are as follows: (1) The Chinese higher education system will have to reform itself in terms of GATS's transparency principle. It will also have to adjust its administration to follow the relevant rules. GATS will force the Chinese higher education system to change some of its policies. (2) GATS will lead to more international exchanges, which will have an impact on Chinese educators' practices. It will introduce new pedagogical models, which may change the Chinese higher education system locally, 
nationally, and internationally. (3) More private and international investors will participate in Chinese higher education. No longer will the state be the only investor. This will alleviate to a certain extent the problem of inadequate funding. (4) As international exchange and cooperation increase and more international education resources become available to Chinese educators, they will update their knowledge more quickly.

At the same time, China is facing serious challenges now that it has made commitments under GATS. The first of these relates to the implications of GATS for the administration of Chinese higher education. GATS promotes the gradual liberalization of educational services. As foreign institutions enter China, conflicts will arise relating to values, concepts, and goals. At the present time, the national government makes the main decisions about policy; however, provincial governments actually administer many of the institutions, which have some autonomy to address local needs. All of these are likely to be affected by GATS. When it comes to market forces, Chinese institutions are about to find themselves at a disadvantage; they all have a great deal to learn.

Second, as China undergoes liberalization in services under GATS, its higher education institutions will find themselves competing with foreign organizations. Since 1999 the number of Chinese higher education students has almost tripled, there are more universities, and they become larger, but there are still not enough higher education institutions, especially quality ones. More institutions in developed countries have noticed this increasing Chinese demand for higher education. In recent years, more and larger international education fairs have been held in China. In 2008 universities from Britain, Australia, Canada, France, Germany, Japan, South Korea, New Zealand, Russia, the United States and other countries sent recruiters to educational exhibitions in China or hired local representatives (China Center for International Educational Exchange, 2009). British and Australian institutions have been particularly aggressive in recruiting Chinese students. To attract international students, some countries have eased their visa requirements and are even allowing international students to work in their countries. In addition, some institutions in developed countries recruit Chinese researchers by offering higher pay and better working conditions. As a consequence, Chinese institutions may lose some of their good instructors and researchers. Top Chinese graduates may want to move to developed countries.

Third, the Internet, economic globalization, and increasing international migration are generating cooperation, as well as conflicts, between societies. It is easier than ever for university students to access a huge variety of cultures and ideas, and this will have an impact on their values and world views (Dai, 2002). 
A recent news report told of a successful Chinese student, Wu Yinyin, at Beijing Normal University. Wu was a senior at the university yet she was already the Asia deputy chief executive of an American company, TopCoder. She had three role models: Madame Curie, Mother Teresa, and Hillary Clinton. None of them is Chinese (Gao, 2007).

\section{ATTITUDES TOWARD FOREIGN EDUCATION}

In 2002 more than 700 residents in three big cities, Beijing, Shanghai, and Guangzhou, were surveyed regarding their attitudes toward foreign education after China joined WTO (National Bureau of Statistics of China, 2002). With respect to preschool education, almost half the respondents (46.5 percent) thought that private educational institutions would be good enough to start children's early education. Some (37.5 percent) thought that public institutions would be better if it was possible to establish such a system. A small percentage of the respondents (16 percent) thought that foreign education would help children ready themselves earlier for elementary school entry. Regarding the years of compulsory education (grade one to grade nine), few respondents favored private education; 96.5 percent had positive views of public education, and only 3.5 percent thought this part of education should be completed in a developed country. When it came to senior secondary school (grades ten to twelve), 76.5 percent continued to prefer public education, but 18.5 percent preferred foreign education, and 5 percent chose private education. The respondents selected the domestic public sector in primary and secondary education because of its low costs and the Chinese higher education entry examination system.

Yet when it came to higher education, domestic institutions were not rated highly. The survey found that 89.5 percent of the respondents were interested in receiving foreign education, 9.5 percent selected domestic publicly funded institutions, and only 1 percent chose domestic private institutions. Many respondents lacked confidence in domestic higher education. They were not satisfied with these institutions' goals, pedagogical models, learning environment and employment opportunities. When asked about various training programs, 70.5 percent selected foreign education, 26.5 percent chose private education, and only 3 percent preferred public education. The following table summarizes the respondents' preferences. 


\begin{tabular}{|l|l|l|l|}
\hline & Public & Foreign & Private \\
\hline Pre-School & 45.6 & 37.5 & 16 \\
\hline Compulsory & 0 & 96.5 & 3.5 \\
\hline Senior secondary & 5 & 76.5 & 18.5 \\
\hline Higher education & 1 & 9.5 & 89.5 \\
\hline Training programs & 26.5 & 3 & 70.5 \\
\hline
\end{tabular}

Table 3.1 Attitudes Toward Foreign Education Survey Results

When asked what the advantages of receiving foreign education were, the respondents offered these opinions: 26.8 percent thought that foreign education would help students learn new ideas and new concepts; 25.7 percent hoped that receiving foreign education would help them develop internationally marketable skills; 25.7 percent believed that foreign education would help them have a better future; 13.4 percent thought that foreign education would make them more efficient; and 8.4 percent expected that foreign education would make them more versatile. Regarding location, 59.9 percent preferred a developed country, 7.6 percent would accept international education providers working in China, and 32.5 percent thought that either would do (National Bureau of Statistics of China, 2002).

Chinese are interested in learning from developed countries, and higher education in China is not as accessible as in developed countries. For these two reasons, among others, some Chinese go overseas for higher education. International education exchanges are enabling Chinese to absorb foreign science and technology as well as recent developments in administration. Learning from developed countries helps China develop its economy and it also helps Chinese educators reform and develop the education system (Chen, 2002).

In improving the higher education system, Chinese educators need to consider issues from a global perspective. They need to be aware of the GATS articles that promote the liberalization of trade in services and make the Chinese higher education system more open. They need to explore opportunities of cooperation with international colleagues $(\mathrm{Ge}, 2005)$.

\section{RECENT DEVELOPMENTS}

One indicator of higher education development is the participation rate. When the participation rate in higher education is between 15 and 50 percent, it is considered mass education (Trow, 1973). In 2008 there were more than 29 million Chinese students in various higher education programs, and the Chinese higher education participation rate was 23 percent (Ministry of Education, July 
17, 2009). The largest in the world, the Chinese higher education system can be considered mass education. Chinese higher education is more accessible than ever before, but there are problems.

There are significant gaps in the development of higher education across regions and social groups, as well as between urban centers and rural areas. These gaps negatively affect some families, especially families in poorer regions, when they try to access higher education. The participation rate does not provide an accurate picture of Chinese higher education. Higher education is still not available in some rural and remote areas. With tuition rising rapidly, higher education is difficult for poor families to access. In addition, the increasing availability of higher education is making people pay more attention to quality, and there are concerns.

On May 10, 2006, the State Council decided that growth in higher education needed to be curtailed so that financial resources could focus more on improving the learning environment. This slowdown would benefit institutions as they adjusted their development. It would also address problems, especially the problem of employment for graduates. The overall goal was to make the growth in higher education sustainable. The size of the higher education system would be stabilized. More attention would be paid to training secondary school students in skills that would make them more employable. Continuing education programs and vocational training programs in secondary schools would be expanded. Some areas of higher education would be more carefully regulated. One problem that needed to be addressed was significant tuition hikes; another was institutions' capacities (China Education Daily, 2006). The government would enhance the quality of higher education (Jiang, 2010) and provide more scholarships and other financial assistance (Wen, 2008).

The international trend in higher education is from elite education to mass, and then to universal education. Problems often accompany this process. In China these problems relate to scale, quality, and funding, as well as employment opportunities for graduates. As Chinese higher education developed from elite to mass education, the problems related to the formerly planned economy and inadequate funding have made the uneven distribution of resources very obvious.

On March 1, 2003, the State Council promulgated the Regulation on SinoForeign Collaborative Education of the People's Republic of China. It states that the national government encourages quality foreign education institutions to cooperate with Chinese counterparts. The government particularly encourages Chinese universities to cooperate with foreign institutions in the fields of administration, finance, law, and technology. 
At present, there are 358 Chinese and foreign cooperative higher education institutes and programs providing instruction to Chinese students (Ministry of Education, October 23, 2009). These institutes and programs have introduced foreign teaching resources into Chinese education. They have made changes in their administrative practices, pedagogy, and curricula. The gradual opening up of Chinese higher education allows Chinese educators to benefit from developed countries' educational resources. It also helps to promote Chinese education in other countries. Currently there are over 400 Confucius institutes and classrooms in 109 countries around the world where people learn Chinese (Sun \& Chen, 2010).

On February 7, 2006, the Ministry of Education announced a decree with respect to the cooperation of Chinese and foreign education institutions. This decree directs provincial education ministries to follow several principles when collaborating with foreign institutions. Among other things, anyone cooperating with foreign institutions must place the public interest first. In addition, Chinese educators and administrators must follow the relevant laws and regulations, play a leading role, protect the interests of all parties involved, and maintain national security and social stability.

In September 2004, the first students entered the campus of the University of Nottingham Ningbo, which has an independent legal person status as well as its own campus. The University of Nottingham Ningbo is the first university built and run cooperatively by Chinese and a foreign university. The Chancellor of Nottingham University in England, Yang Fujia, is the Chancellor of Nottingham Ningbo. The University of Nottingham Ningbo follows the curriculum and evaluation procedures of Nottingham University in England, which selects instructors for Nottingham Ningbo. Instruction is provided in English. The license to operate Nottingham Ningbo is valid until 2055 (Ministry of Education, September 5, 2007). On graduation, students will be conferred a Chinese undergraduate graduation certificate and a bachelor's degree from Nottingham University. The student numbers at Nottingham Ningbo grew from 250 in 2004 to 4,343 in 2009 (Woods, 2009). In September 2006, the first students entered the campus of Xi'an Jiaotong-Liverpool University in Suzhou, which is a joint venture of Xi' an Jiaotong University and the University of Liverpool. The license for Xi' an Jiaotong-Liverpool University is valid to 2056 (Ministry of Education, September 5, 2007; Xi' an Jiaotong University, 2008).

China has gone through a tremendous change since it started opening up in 1978. The economy has been fundamentally transformed, and as a result the Chinese labor market is undergoing important changes. To meet the requirements of the changing labor market, today Chinese higher educators consider the 
balance of supply and demand and pay more attention to societal transformation. In addition, when compared with the past, the national government has given considerable autonomy to universities (Yang, Vidovich, \& Currie, 2007).

On July 12, 2006, the Third International Chinese and Foreign University Presidents' Forum was held in Shanghai. University presidents from the United States, Britain, Canada, Australia, Japan, and other countries attended the forum to discuss how universities can better serve economic and social development. The Chinese Minister of Education, Zhou Ji, met with some of the foreign university presidents in attendance, confirmed that international cooperation was having a positive impact on Chinese education, and encouraged his guests to strengthen their cooperation with Chinese colleagues (Ministry of Education, July 12, 2006). On April 6, 2007, the Ministry of Education proclaimed a decree to provide more detailed rules for cooperation between Chinese and foreign higher education institutions.

On June 16, 2007, the Beijing 21st Century Experimental School announced that it would open an American Advanced Placement Program in the fall. Within several days over 200 people consulted the school, and more than 60 secondary school students applied (Fang \& Li, 2007). Most applicants interested in the program intended to go to study in an American university.

\section{CONCLUSIONS}

Signing GATS has implications for Chinese higher education. It has brought real opportunities as well as serious challenges. The impact GATS will have on a country's higher education system depends on: 1) the country's economic and political position, 2) the structure of the education sector and level of existing services, and 3) the mode of service delivery (Vlk, 2006). Across the world the demand for international education is forecast to increase (Raychaudhuri \& De, 2007). There is an enormous appetite for higher education in densely populated countries that want to build human capital to fully participate in the knowledge society (Knight, 2006). In 2008 approximately 10 million Chinese took the entry examinations for higher education; only about 6 million were admitted (Ministry of Education, July 17, 2009). There is clearly a growing demand for higher education in China.

Although there are questions and different opinions (Healey, 2007), internationalization is a positive and inevitable element of global higher education (Altbach, 2008). In developing higher education, Chinese have learned from the United States, Britain, Australia, Japan, Germany, and the Soviet Union. For Chinese educators, learning from the developed countries is an important task (Liao, Tan, \& Zhu, 2008). We believe following the relevant GATS rules is 
conducive to the development of Chinese higher education. In the debate about the implications of GATS and internationalization, most Chinese scholars think GATS and internationalization will have a positive influence on Chinese higher education (Chen, 2002; Dai, 2002; Ge, 2005; Guan, 2006; Huang, 2010; Liao, Tan, \& Zhu, 2008; Meng, 2006; Wu, 2002; Yang, Vidovich \& Currie, 2007).

Chinese are interested in learning from developed countries, the Chinese government has made a commitment to gradually open its higher education, it encourages international cooperation, the demand for higher education continues to grow, foreign providers are meeting part of this demand, China's recent move to mass higher education has turned more and more to the market for needed resources (Zha, 2009), and market ideologies may be a stronger influence in Chinese higher education (Yang, Vidovich, \& Currie, 2007). Indications are that in seizing opportunities and dealing with challenges, Chinese educators will expand their cooperation with international colleagues to meet the changing needs of society. In the process of internationalizing Chinese higher education, GATS may play a facilitating role. Since the Chinese higher education system is the largest in the world, its internationalization may have an impact on higher education systems in other countries.

\section{References}

Altbach, P. (2008). The "subprime" market and international higher education. International Higher Education, 51. Retrieved May 29, 2008, from http://www.bc.edu/bc_org/avp/soe/cihe/newsletter/Number51/p2_Altbach.htm

Canadian Association of University Teachers. (2006, January). Education targeted in WTO talks. CAUT Bulletin, A1.

Chen, Zhili. (2002, January 9). 我国加入WTO对教育的影响及对策研究 [Accession to WTO: Its implications for education and our strategies]. China Education Daily, 1.

China Center for International Educational Exchange. (2009). 2008 Exhibitor List. Retrieved November 29, 2009 from http://www.chinaeducationexpo.com/english/exhibition/2008previous_event.html China Education Daily. (2006, May 11). 1.

Czernis, L. (2005, December). Higher education not for trade. CAUT Bulletin, A3.

Dai, Yuenong. (2002). 趋利避害: 加入WTO后中国高等教育发展之取向 [Enjoying the benefits but avoiding the harms: Accession to WTO and the direction of Chinese higher education development]. Research in Educational Development, 7. Retrieved July 10, 2008, from http://scholar.ilib.cn/A-jyfzyj200207007.html

Education International. (2008). Doha ministerial collapses: WTO members vow to regroup. Retrieved August 19, 2008, from http://www.ei-ie.org/gats/en/newsshow.php?id=836\&theme=gats\&country=global

Fang, C., \& Li, Y. (2007, June 28). Why are they interested in an American university? People's Daily Overseas Edition, 4

Gao, R. (2007, July 18). Wu Yinyin: A life full of competitions. People's Daily Overseas Edition, 7.

Ge, Ling. (2005, July 18). WTO与教育国际化的思考 [WTO and the internationalization of Chinese education]. Retrieved February 23, 2010, from http://www.ep-china.net/article/strategic/2005/07/20050718201714.htm

Guan, Naijia. (2006). The strategy for internationalization of universities in China. Presentation given at the International Association of Universities Conference: Internationalization of Higher Education, October 15, 2006, Beijing, China. Retrieved June 3, 2008, from http://www.unesco.org/iau/conferences/china/pdf/IAU-CEAIE_JointSession_01_Naijia_Guan.pdf

Healey, N. (2007). Is higher education in really "internationalizing"? High Education, $\overline{5} 5$, 333-355.

Huang, J. (2010, February 3). 大学国际化不单是 “接轨” [University internationalization is not simply "connecting tracks"]. Guangming Daily. Retrieved February 23, 2010, from http://www.gmw.cn/content/2010-02/03/content_1049184.htm 
Jiang, K. (2010). Undergraduate teaching evaluation in China: Progress and debate. International Higher Education, $58 . \quad$ Retrieved $\quad$ February 20, 2010, from http://www.bc.edu/bc_org/avp/soe/cihe/newsletter/Number58/p15_Jiang.htm

Knight, Jane. (2006). The new world of crossborder education: Concepts, complexities and challenges. Paper presented at the Annual Conference of Canadian Society for the Study of Education, York University, Toronto, Canada, May 27-June 1, 2006. Retrieved June 2, 2008, from http://www.csse.ca/CCGSE/docs/CCSEProceedings3JaneKnight.pdf

Liao, J., Tan, G., \& Zhu, X. (2008). 我国大学教育国际化的路径选择 [What approach should we adopt in internationalizing higher education?] Chinese Higher Education, 1. Retrieved August 20, 2008, from http://www.ep-china.net/article/strategic/2008/05/20080529083624.htm

Lu, P., \& Zha, W. (2004). 美国参与《服务贸易总协定（GATS）》教育服务贸易谈判的主要考虑及策略 [The main US GATS considerations and its strategies in negotiations on trade in services related to education]. $\begin{array}{llll}\text { Retrieved June } & 2, & \text { from }\end{array}$ http://www.moe.edu.cn/edoas/website18/level3.jsp?tablename=1680\&infoid=19747

Meng, Yang. (2006). Promoting education exchange on partnership. Presentation given at the International Association of Universities Conference: Internationalization of Higher Education, October 15, 2006, Beijing, China. Retrieved June 5, 2008, from http://www.unesco.org/iau/conferences/china/pdf/IAUCEAIE_JointSession_05_Yang_Meng.pdf

Ministry of Education. (2006, February 7). 教育部关于当前中外合作办学若干问题的意见 [Ministry Decree on the Cooperation Between Chinese and Foreign Institutions]. Retrieved June 3, 2008, from http://www.moe.gov.cn/edoas/website18/31/info18331.htm

Ministry of Education. (2006, July 12). 第三届中外大学校长论坛在上海开幕 [The Third Shanghai International University Presidents' Forum opened]. Retrieved June 6, 2008, from http://www.moe.gov.cn/edoas/website18/62/info20762.htm

Ministry of Education. (2007, April 6). 教育部关于进一步规范中外合作办学秩序的通知 [Ministry Decree on the Further Standardization of Chinese and Foreign Co-Operation in Running Schools]. Retrieved August 18, 2008, from http://www.moe.gov.cn/edoas/website18/55/info27355.htm

Ministry of Education. (2007, September 5). 宁波诺丁汉大学中外合作办学机构信息表 [The University of Nottingham Ningbo: The Sino-Foreign Collaborative Institute Information Form]. Retrieved June 9, 2008, from http://www.moe.gov.cn/edoas/website18/87/info24287.htm; 西交利物浦大学中外合作办学机构信息表 [Xi'an Jiaotong-Liverpool University: The Sino-Foreign Collaborative Institute Information Form]. Retrieved June 10, 2008, from http://www.moe.gov.cn/edoas/website18/65/info24265.htm

Ministry of Education. (2009, March 25). 教育部2009年第6次新闻发布会 介绍2008年中国教育对外开放总体情况及出国留学、来华留学事业发展情况 [The Ministry of Education $20096^{\text {th }}$ News Conference: International Exchanges and Co-operations in Chinese Education, Chinese Going Overseas for Education, and Foreigners Coming to China for Education]. Retrieved November 29, 2009, from http://www.moe.gov.cn/edoas/website18/02/info1237941653766102.htm

Ministry of Education. (2009, July 17). 2008年全国教育事业发展统计公报 [2008 National Education Development Statistics Bulletin]. Retrieved February 5, 2010, from http://www.moe.gov.cn/edoas/website18/28/info1262244458513828.htm

Ministry of Education. (2009, October 23). 关于公布中外合作办学机构和项目相关信息的说明 [An Explanation of the Information on Sino-Foreign Collaborative Institutes and Programs]. Retrieved February 5, 2010, from http://www.crs.jsj.edu.cn/article_read.php?id=12-19700101-59

Ministry of Education. (2009, December 4). 在华学习的外国学生总数近23万人 [Foreign students studying in China total almost 230,000]. Retrieved February 23, 2010, from http://www.moe.gov.cn/edoas/website18/52/info1259926034882452.htm

Nankai University. (2007). 南开大学首位外国院长到任 [First foreign dean arrived at Nankai]. Retrieved August, 17, 2008, from http://user.nankai.edu.cn/WSW/Pub/Content.aspx?ID=827

National Bureau of Statistics of China. (2002). 89.5\%的人倾心外国高等教育 [89.5\% respondents interested in foreign higher education]. Retrieved August 11, 2008, from http://www.stats.gov.cn/tjfx/rddc/t20020531_21041.htm 
Raychaudhuri, P., \& De, P. (2007). Barriers to trade in higher education services: Empirical evidence from AsiaPacific countries. Retrieved May 16, 2008, from http://www.unescap.org/tid/ publication/aptir2470_ajitava_prabir.pdf

Robertson, S. (2003). WTO/GATS and the global education services industry. Globalisation, Societies and Education, 1(3), 259-266.

State Council. (2003). The Regulation on Sino- Foreign Collaborative Education of the People's Republic of China. Retrieved February 22, 2010, from http://www.moe.edu.cn/english/laws_r.htm

Sun, W., \& Chen, Y. (2010, January 15). Improving overseas Chinese teaching and meeting the high demand for training of Chinese teachers. People's Daily Overseas Edition, 2.

Trow, M. (1973). Problems in the Transition from Elite to Mass Higher Education. New York: Carnegie Commission on Higher Education.

Varoglu, Z. (2002). Trade in higher education and GATS basics. Document distributed for Division of Higher Education, Section for Access, Mobility and Quality Assurance, UNESCO, at First Global Forum on International Quality Assurance, Accreditation and the Recognition of Qualifications in Higher Education: Globalization and Higher Education, October 17-18, 2002, Paris. Retrieved May 28, 2008, from http://www.aic.lv/bolona/Bologna/Bol_semin/Oth_conf/UNESCO_GF1/gf8_tradehe_gats_basics.pdf

Verger, A. (2008). Measuring educational liberalization: A global analysis of GATS. Globalisation, Societies and Education, 6(1), 13-31.

Vlk, A. (2006). Higher education and GATS: Regulatory consequences and stakeholders' responses. Doctoral dissertation at University of Twente, Enschede, the Netherlands. Retrieved May 12, 2008, from $\mathrm{http}: / /$ www.utwente.nl/cheps/documenten/thesisvlk.pdf

Wen, Jiabao. (2008, March 6). A report on the central government's work. People's Daily Overseas Edition, 3.

Woods, R. (2009). Academic excellence in the service of global citizenship: The University of Nottingham Ningbo, China. Presentation to the Global Forum held in Kuala Lumpur, Malaysia. Retrieved February 22, 2010, from http://www.obhe.ahttp://www.obhe.ac.uk/the_obhe_global_forum_malaysia/Academic_Excellence_in_the_Se rvice_of_Global_Citizenship.pdf

WTO. (1991). Services sectoral classification list. Retrieved July 20, 2008, from http://www.wto.org/english/tratop_e/serv_e/mtn_gns_w_120_e.doc

WTO. (1994). General Agreement on Trade in Services. Retrieved July 31, 2008, from http://www.wto.org/english/docs_e/legal_e/26-gats_01_e.htm\#articleXIII

WTO. (2002). Manual on Statistics of International Trade in Services. Retrieved June 14, 2008, from http://unstats.un.org/unsd/tradeserv/TFSITS/MSITS/m86_english.pdf

WTO. (2002, February 14). GATS/SC/135 (02-0796), Trade in Services, THE PEOPLE'S REPUBLIC OF CHINA, Schedule of Specific Commitments. Retrieved June 15, 2008, from http://www.wto.org/english/tratop_e/serv_e/serv_commitments_e.htm

WTO. (2006). Understanding the WTO: basics. Retrieved May 28, 2008, from http://www.wto.org/english/thewto_e/whatis_e/tif_e/fact2_e.htm

$\mathrm{Wu}$, Yan. (2002, January 19). 从教育承诺看WT0的影响 [WTO's implications after the promise to open our education sector]. China Education Daily.

Xi'an Jiaotong University (2008). 西交利物浦大学 [Xi'an Jiaotong-Liverpool University]. Retrieved June 18, 2008, from http://www.xjtu.edu.cn/hzjl/xjlwpdx.html

Yang, R., Vidovich, L., \& Currie, J. (2007). "Dancing in cages": Changing autonomy in Chinese higher education. High Education, 54, 575-592.

Zha, Q. (2009). Diversification or homogenization: how governments \& markets have combined to (re)shape Chinese higher education in its recent massification process. Higher Education, 58(1), 41-58. Retrieved August 28, 2009, from http://www.springerlink.com.proxy.library.brocku.ca/content/44217643h4322 r17/fulltext.pdf

Zhang Xinsheng. (2008, August 15). 教育部副部长章新胜介绍中国教育开放与国际合作等方面情况 [Deputy Minister of Education Zhang Xinsheng: The opening up and international cooperation of Chinese education]. Retrieved August 15, 2008, from http://www.moe.gov.cn/edoas/website18/83/info1218778117003283.htm

Xiaobin Li (xli@brocku.ca) is an Associate Professor at Brock University with research interests in Chinese education, education finance, education law, and quantitative methods in education research.

LinbinZhao (zhaolb@pub2.fz.fj.cn) is a Professor at Minjiang University, Fuzhou, Fujian, China. His research interests include Chinese higher education and economic reform in China. 